\title{
Does globalization accelerate economic growth? South Asian experience using panel data
}

\author{
Md Abu Hasan ${ }^{1,2^{*}}$ (]
}

*Correspondence:

hhafij@yahoo.com

${ }^{1}$ Bangladesh Civil Service

(General Education), Ministry

of Education, Dhaka,

Bangladesh

Full list of author information is available at the end of the article

\begin{abstract}
The paper investigates the impact of globalization (overall, economic, social, and political) on economic growth of South Asian countries over the period from 1971 to 2014 employing cross-sectional dependence test, Cross sectionally Augmented Dickey-Fuller (CADF) unit root test (Pesaran in J Appl Econ 22(2):265-312 https://doi. org/10.1002/jae.951, 2007), and Pooled Mean Group (PMG) panel cointegration model (Pesaran et al. in J Am Stat Assoc 94(446):621-634, 1999). Results report that overall globalization, economic globalization, and political globalization accelerate economic growth in the long-run; however, the dimensions of globalization have no significant effect in the short-run. Focusing on the individual country regressions, we find the amalgam results, as the characteristics, elasticity, and strength of political, social, and economic institutions are different in the selected countries. The policy implication is that the governments of South Asian countries should realize the importance of globalization as a powerful influencing force and should adopt the new circumstances of globalization quickly and try to find coherent policies to be connected with an evolving world.
\end{abstract}

Keywords: Economic globalization, Economic growth, Panel data analysis, Pooled mean group

JEL Classification: C33, F02, F40, F62

\section{Introduction}

Economic growth has long been considered as a central macroeconomic goal of economic policy, and thus, a substantial body of research has been performed over the years to explain how this goal is successfully accomplished. Though South Asian ${ }^{1}$ countries still stay behind than of world benchmarks based on most economic and social indicators, according to the average annual growth of GDP, the South Asian region experiences an average $5.4 \%$ annual growth, while the world average is only $3.1 \%$ over the recent five decades (World Bank 2017a). Most interestingly, the performances of the South Asian economy during the 21st century have been quite impressive as the average GDP growth has been increased to $6.82 \%$ per annum, while the world average is decreased

\footnotetext{
${ }^{1}$ The World Factbook, based on geopolitics, people, and economy defines South Asia as comprising Afghanistan, Bang ladesh, Bhutan, India, Maldives, Nepal, Pakistan, and Sri Lanka.
} 
to 2.78\% (World Bank 2017b). In (2017), the Asian Development Bank (ADB) predicts that South Asia's economy as a whole is anticipated to rise to $7 \%$ in 2017, progressing to $7.2 \%$ in 2018. With a combined population of about 1.75 billion or about one-fourth of the world's population, South Asia consolidates its position as the global leader in economic growth, and the forces that determine such economic growth are worthy of investigation. Investigations related to economic growth may be approached from different perspectives; however, this study focuses on globalization and its impact on economic growth. Though the term 'globalization' was introduced in the early 1980s, its historical roots run deep. Over the past few decades, globalization has become a frequently used word in the political economy but, so far, there is no consensus on a single definition of it. Globalization is an old phenomenon with a new appearance and usually defined as an expansion of global linkages among nations. According to UNDP (1999, p. 25): "Globalization, a dominant force in the 20th century's last decade, is shaping a new era of interaction among nations, economies and people. It is increasing the contacts between people across national boundaries in economy, in technology, in culture and in governance." Rothenberg (2003) states, "Globalization is the acceleration and intensification of interaction and integration among the people, companies, and governments of different nations" (p. 1). Today, globalization turns out to be a multidimensional concept as it covers a lot of areas, such as economic, political, and social areas.

Uncovering the effect of globalization on economic growth is worthy in the era of globalization as the net impact of globalization on economic growth still remains puzzling. Bhattacharya (2004) argues that a substantial proportion of people and countries continue to remain excluded from the rewards of globalization for the asymmetrical nature of the process even though it yields a bunch of benefits including greater freedom of choice, lower prices of goods, and higher income for individuals (p. 7). Benefits from globalization are not just spread unevenly between developed and developing countries, even within countries there is often unequal distribution of benefits (United Nations 2004, p. 229). Kilic (2015) contends that even though the globalization generates opportunities for some countries' economies and positively promoting their economic growth, it also triggers off poverty, inequality, and negative economic growth for others (p. 1). In her speech under the agenda item on globalization and interdependence on October 23, 2013, the United Nations Assistant Secretary-General for economic affairs, Akhtar (2013), briefly informed the audience that "...it remains a challenge to ensure that all countries and all people benefit from globalization's full potential. Global forces, such as trade and cross-border flows of capital and labor, have created opportunities for some and negative consequences for others." So, it goes without saying that the globalization is under threat; however, World Bank (2017a) has come up with a report and argues that the prospects for the South Asian region are better than it seems and globalization has been good for development, and trade has been crucial to poverty reduction (p. 26). Most importantly, the current globalization backlash should not deter the South Asian region from having a stronger outward orientation (p. 25). Moreover, Dreher (2005) argues, "contrary to the beliefs of its critics, globalization indeed promotes growth" (p. 13). Above and beyond, the existing empirical studies regarding the effect of globalization on economic growth are also ambiguous. The consequence of economic globalization on economic growth has been frequently analyzed with a number of data and 
methods, and most of these studies suffer from econometrics shortcoming and narrow definition of globalization. A large number of empirical studies that look at the comprehensive effects of globalization on economic growth are done after 2006, while studies in the context of South Asian countries have basically been ignored. Thus, as a fastest growing region in the world and having enormous growth potential, a study on the effect of economic, social, and political globalization on the economic growth in South Asia is important, especially for economic policies. This paper aims to fill this void by comprehensively investigating the impact of economic, social, and political globalization on the economic growth in South Asia employing advance econometric methodology. It is believed that by employing modern panel econometric tools, such as cross-sectional dependence test, CADF unit root test (Pesaran 2007), and PMG panel cointegration analysis (Pesaran et al. 1999) on KOF globalization and real GDP growth data, the results will capture the true picture of the impacts of globalization compared to the previous studies.

The introduction part of this paper states the problem and gives some light on the motivation and the significance of the research. The rest of this study is organized in four sections as follows: Sect. 2 presents a brief literature review; Sect. 3 explains about the data and methodology; Sect. 4 reports the empirical findings; and finally, Sect. 5 concludes this study.

\section{Related literature}

Dreher (2006) presents an index of comprehensive globalization covering its three main dimensions: economic integration, social integration, and political integration. Then he analyzes the relation between globalization and economic growth employing panel data technique for 123 countries over the period from 1970 to 2000 . He finds out that globalization indeed promotes growth, whereas political integration does not affect. Barry (2010) analyzes the influence of KOF globalization index on economic growth in sub-Saharan Africa using panel data from 1995 to 2005 for 41 countries. Employing an Ordinary Least Squares (OLS) model, the study shows that globalization has a positive, though statistically insignificant, impact on the economic growth of sub-Saharan Africa. Polasek and Sellner (2011) examine globalization's effects on the regional growth of the 27 European Union (EU-27) countries covering the period from 2001 to 2006. Applying the Spatial Chow-Lin Procedure, which is formed by writers, they find that globalization (foreign direct investment and trade gap) affects many region's economic growth in a positive way. Moghaddam and Redzuan (2012) investigate the globalization indicators for measuring and evaluating the economic development scale of eight selected countries (Brazil, China, India, Korean Republic, Malaysia, Singapore, Iran, and Turkey). They find that the rise of FDI as a percentage of GDP and attraction of FDI in these countries have influenced positively on foreign trade at international and regional levels. Ying et al. (2014) operate panel data analysis to examine the influence of shortrun dynamics and long-run equilibrium relationships between globalization and the growth of ASEAN countries between 1970 and 2008. Dividing globalization into three categories and employing panel cointegration tests developed by Pedroni (1999, 2001, 2004), this study finds that globalization has a strong integrated relationship with economic growth. Using panel fully modified OLS (FMOLS), they reveal that the elasticity 
of economic growth with respect to economic globalization is 1.48, indicating that economic globalization has a significantly positive influence on economic growth. However, the results also show that social globalization has a negative influence on economic growth, while political globalization has a non-significant negative effect. Kilic (2015) tests the effects of economic, social, and political globalization on the growth levels of 74 developing countries between 1981 and 2011 period by using fixed effects least squares method and Granger causality test developed by Dumitrescu and Hurlin (2012). The results of his study reveal that economic growth of selected developing countries is positively affected by the economic and political globalization, while social globalization upsets economic growth negatively. Furthermore, the paper finds a bidirectional causal relationship between political and social globalization and economic growth, whereas one-way causality exists between social globalization and economic growth. In a recent time series study, Maqbool-ur-Rahman (2015) investigates the impact of globalization index developed by Dreher (2006) on GDP data of three South Asian countries (Pakistan, India, and Bangladesh) for the period from 1981 to 2011. Employing ordinary least square (OLS) and Granger causality methods, he explores that globalization and GDP both affect each other and demonstrates bidirectional causality in India, while Pakistan and Bangladesh present unidirectional causality between globalization and GDP.

\section{Data and methodology}

\subsection{Data and model}

When researchers investigate the influences of globalization on economic growth, several measures of globalization are kept in mind owing to its multidimensional character. Most of them concentrate on the classic indicator of globalization that is its economic dimension. Dreher (2005) realizes the importance to calculate a comprehensive globalization index and states that:

From a policy perspective, of course, the influences of individual elements of globalization on economic policy are important. However, most elements of globalization are highly correlated, so that it is impossible to include them all individually in one regression. Omitting dimensions, on the other hand, causes coefficients to be biased. Using an aggregate indicator of globalization is thus preferable. In any case, only an aggregate measure can be used to study the overall effect of globalization. (p. 401)

After that, an overall globalization index along with three sub globalization index (economic, social, and political), named KOF (Konjunkturforschungsstelle) Index of Globalization comes out by Dreher (2006) and upgraded by Dreher et al. (2008). KOF index of globalization ranges from zero to hundred, where larger KOF index implies that a country is in higher globalization. Economic, social, and political globalization in the overall index of the globalization of 2017 is 36\%, 37\%, and 27\%, respectively (KOF Index of Globalization 2017; see Appendix for details).

This study uses annual data of five South Asian countries, such as Bangladesh, Bhutan, India, Nepal, and Pakistan on real GDP growth (proxied for economic growth), KOF overall globalization index, economic globalization index, social globalization index, and political globalization index over the period from 1971 to 2014 for the panel data analysis. The data on real GDP growth at constant US dollar 2005 price are collected from 
World Development Indicators, 2017, published by World Bank, while the globalization index data are collected from KOF globalization index database. This restriction is on the five countries of South Asia due to unavailability of the 1970s and 1980s data either on GDP or globalization of Afghanistan, Maldives, and Sri Lanka. The analysis is done using the EViews 9 and Stata 12 econometric software packages. We estimate the following two models to measure the impacts of globalization on economic growth by considering data sample of five South Asian countries:

$$
\begin{aligned}
& \text { Model 1: } Y_{i t}=\alpha_{i}+\beta_{i} \mathrm{OG}_{i t}+\varepsilon_{i t}, \\
& \text { Model 2: } Y_{i t}=\alpha_{i}+\beta_{1} \mathrm{EG}_{i t}+\beta_{2} \mathrm{SG}_{i t}+\beta_{3} \mathrm{PG}_{i t}+\varepsilon_{i t},
\end{aligned}
$$

where $Y$ : economic growth, OG: Overall Globalization Index, EG: Economic Globalization Index, SG: Social Globalization Index, PG: Political Globalization Index, $i$ denotes a country, and $t$ denotes a year.

\subsection{Econometric methodology}

\subsubsection{Cross-sectional dependency test}

Panel datasets often display considerable cross-sectional dependence, which may arise due to the presence of common shocks and unobserved components (Hoyos and Sarafidis 2006, p. 482). Pesaran (2006) gives importance of testing the cross-sectional dependence in a panel study and performing the Monte Carlo experiment. He shows that there exist the substantial bias and size distortions when cross-sectional dependency is ignored leading to estimations (cited in Kilic 2015, p. 5). Moreover, Shariff and Hamzah (2015) argue that problems arise in testing the stationarity of the panel in the presence of cross-sectional dependence and outliers (p. 159). Therefore, the existence of cross-sectional dependency of this study has been checked with $\mathrm{CD}_{\mathrm{LM}}$ (Breusch and Pagan 1980), CD (Pesaran 2004), $\mathrm{CD}_{\mathrm{LM}}$ (Pesaran 2004), and adjusted $\mathrm{CD}_{\mathrm{LM}}$ (Pesaran et al. 2008) tests. Since time dimension in our study is bigger than cross section, we will provide importance on the results of $\mathrm{CD}_{\mathrm{LM}}$ test of Breusch and Pagan (1980) and adjusted $\mathrm{CD}_{\mathrm{LM}}$ test of Pesaran et al. (2008) test.

Breusch and Pagan (1980) propose an LM statistic, which is valid for fixed $N$ as $T \rightarrow \infty$ and is given by

$$
\mathrm{LM}=T \sum_{i=1}^{N-1} \sum_{j=i+1}^{N} \widehat{\left(\rho_{i j}^{2}\right)} \sim \frac{\chi^{2} N(N-1)}{2} .
$$

Pesaran et al. (2008) develop a bias-adjusted LM test by using the exact mean and variance of the LM statistic as shown in Eq. (4) (p. 108):

$$
\mathrm{LM}_{\mathrm{adj}}=\sqrt{\left\{\frac{2 T}{N(N-1)}\right\}} \sum_{i=1}^{N-1} \sum_{j=i+1}^{N} \widehat{\rho_{i j}} \frac{(T-k) \widehat{\rho}_{i j}^{2}-\mu_{T i j}}{\sqrt{V_{T i j}^{2}}},
$$

where $\mu_{T i j}$ and $V_{T i j}^{2}$ are, respectively, the exact mean and variance of $(T-k) \widehat{\rho}_{i j}^{2}$. Under the null hypothesis with first $T \rightarrow \infty$ and then $N \rightarrow \infty, \mathrm{LM}_{\text {adj }}$ test is asymptotically distributed as standard normal. Null and alternative hypotheses of cross-sectional dependency test are shown below: $\mathrm{H}_{0}$ : there is no cross-sectional dependence among the 
countries in the panel; $\mathrm{H}_{1}$ : there is cross-sectional dependence among the countries in the panel.

\subsubsection{Unit root test}

The estimations may be biased while the unit root test is conducted without considering the cross-sectional dependency. First-generation unit root tests do not consider the cross-sectional dependency while it is making unit root testing. Thus, considering the potential cross-sectional dependence, we employ a widely used second-generation unit root test developed by Pesaran (2007), namely, Cross Sectionally Augmented DickeyFuller (CADF) test that allows cross section dependence in the panel data.

Pesaran augmented the conventional ADF regression model with the lagged cross-sectional average and its first difference to obtain the cross sectionally augmented DickeyFuller (CADF) test:

$$
\Delta Y_{i t}=\alpha_{i}+\beta_{i} Y_{i t-1}+\gamma_{i} \bar{Y}_{t-1}+\phi_{i} \Delta \bar{Y}_{t}+\varepsilon_{i t},
$$

where the standard of Augmented Dickey-Fuller (ADF) model is extended up to more variables in independent variables in the model (5), that is, cross section averages of lagged levels $\left(\bar{Y}_{t-1}\right)$ and first differences of the individual series $\left(\Delta \bar{Y}_{t}\right), i$ in the model. Pesaran has attested that the impact of $C D$ can be eliminated by using model (5).

From estimating the CADF regression for each cross section, $t$ statistics are obtained and subsequently, the CIPS (cross-sectional augmented IPS) statistic can be found from the mean value of the $t$ statistics:

$$
\mathrm{CIPS}=\frac{1}{N} \sum_{i=1}^{N} \mathrm{CADF}_{i}
$$

The CIPS test yields more precise and reliable results in the presence of cross-sectional dependence than those of the first-generation tests.

\subsubsection{Panel cointegration test}

This study applies a panel ARDL model, or Pooled Mean Group (PMG) estimation, proposed by Pesaran et al. (1999) which enables to capture the long-run and short-run relationship among the variables of interest and it can also include the $\mathrm{I}(0)$ and $\mathrm{I}(1)$ series together (p. 625). Following Ren et al. (2012), an autoregressive distributive lag, ARDL( $p$, $q_{1}, \ldots, q_{k}$ ) is represented as follows (p. 1352):

$$
\Delta Y_{i t}=\emptyset_{i}\left(Y_{i, t-1}-\beta_{i} X_{i, t-1}\right)+\sum_{j=1}^{p-1} \lambda_{i j} Y_{i, t-j}+\sum_{j=0}^{q-1} Y_{i, j} X_{i, t-j}+\mu_{i}+u_{i j},
$$

where $Y_{i t}$ is a scalar-dependent variable (economic growth); $X_{i t}$ is the $k \times 1$ vector of regressors (institution variables) for group $i ; \mu_{i}$ represents the country-specific effects (fixed effects); $\emptyset_{i}$ is a scalar coefficient on the lagged dependent variable; $\beta_{t}$ is the $k \times 1$ vector of coefficients on explanatory variables; $\lambda_{i j}$ are scalar coefficients on lagged first differences of dependent variables; and $Y_{i, j}$ are $k \times 1$ coefficient vectors on first difference of explanatory variables and their lagged values. We assume that the disturbances $u_{i j}$ are 
Table 1 Results of cross-sectional dependence tests

\begin{tabular}{llllll}
\hline Levels & $\boldsymbol{Y}$ & OG & EG & SG & PG \\
\hline $\mathrm{CD}_{\mathrm{LM}}$ (Breusch and Pagan & $20.16^{* *}$ & $339.64^{* * *}$ & $313.91^{* * *}$ & $327.91^{* * *}$ & $286.66^{* * *}$ \\
$1980)$ & $(0.027)$ & $(0.00)$ & $(0.00)$ & $(0.00)$ & $(0.00)$ \\
$\mathrm{CD}_{\mathrm{LM}}$ (Pesaran 2004) & $2.27^{* *}$ & $73.71^{* * *}$ & $67.96^{* * *}$ & $71.09^{* * *}$ & $61.86^{* * *}$ \\
& $(0.023)$ & $(0.00)$ & $(0.00)$ & $(0.00)$ & $(0.00)$ \\
$\mathrm{CD}$ (Pesaran 2004) & $2.41^{* *}$ & $18.20^{* * *}$ & $17.47^{* * *}$ & $17.93^{* * *}$ & $16.47^{* * *}$ \\
& $(0.016)$ & $(0.00)$ & $(0.00)$ & $(0.00)$ & $(0.00)$ \\
LM $_{\text {adj }}$ (Pesaran et al. 2008) & $2.21^{* *}$ & $73.65^{* * *}$ & $67.89^{* * *}$ & $71.03^{* * *}$ & $61.80^{* * *}$ \\
& $(0.026)$ & $(0.00)$ & $(0.00)$ & $(0.00)$ & $(0.00)$ \\
\hline
\end{tabular}

$P$ values of the corresponding statistics are in parentheses. ** and ${ }^{* * *}$ indicate statistical significance at the $5 \%$ and $1 \%$ levels, respectively

independently distributed across $\mathrm{i}$ and $\mathrm{t}$. Further assuming that $\emptyset_{i}(0$ for all $i$ and therefore there exists a long-run relationship between $Y_{i t}$ and $X_{i, t}$ ):

$$
Y_{i t}=\widehat{\theta_{i j}} X_{i j}+\eta_{i j} \quad i=1,2 \ldots N ; \quad t=1,2, \ldots T,
$$

where $\widehat{\theta_{i j}}=\frac{\widehat{\beta}_{t}}{\phi_{i}}$ is the $k \times 1$ vector of the long-run coefficients and $\eta_{i j}$ is stationary with possibly nonzero means (including fixed effects). Equation (7) can be rewritten as the VECM system as follows:

$$
\Delta Y_{i t}=\emptyset_{i} \eta_{i, t-1}+\sum_{j=1}^{p-1} \lambda_{i j} \Delta Y_{i, t-1}+\sum_{j=0}^{q-1} Y_{i, j} \Delta X_{i, t-j}+\mu_{i}+u_{i j}
$$

where $\eta_{i, t-1}$ is the error correction term given by (9); hence $\emptyset_{i}$ is the error correction coefficient measuring the speed of adjustment towards the long-run equilibrium.

\section{Findings}

Table 1 shows the cross-sectional dependence test results. As seen in the table, the null hypothesis is rejected since probability values of the variables are smaller than 0.05 meaning that there is a cross-sectional dependency on all variables. This result implies that any change or shock in the selected variables in any of the panel countries also affects other countries as well. Because of this, second-generation unit root test that takes into consideration the cross-sectional dependency is employed while unit root specifications of series are checked.

Results of CIPS statistic of CADF unit root test are shown in Table 2. As shown in Table 2, the test rejects the null hypothesis of the unit root for the variables of $Y$ and OG in the constant model at $1 \%$ and 5\% significance level, respectively. Adding both constant and trend terms in the model, the test reveals that OG, EG, SG, and PG series are non-stationary and $Y$ series is stationary in levels. Results from the CIPS tests also show that all series are stationary in first differences with $1 \%$ significance level. So, the individual series are found to be either $\mathrm{I}(0)$ or $\mathrm{I}(1)$, while none of the variables are integrated of order two. Thus, we proceed to apply the Pooled Mean Group (PMG) cointegration procedure proposed by Pesaran et al. (1999) as it can incorporate I(0) and I(1) variables in the same estimation. 
Table 2 Results of Pesaran's CADF test

\begin{tabular}{|c|c|c|c|c|}
\hline \multirow[t]{2}{*}{ Variables } & \multicolumn{2}{|l|}{ Constant } & \multicolumn{2}{|c|}{ Constant and trend } \\
\hline & $t$ bar & $P$ value & $t$ bar & $P$ value \\
\hline Y & $-3.46^{* * *}$ & 0.00 & $-4.17^{* * *}$ & 0.00 \\
\hline OG & $-2.55^{* *}$ & 0.03 & -2.68 & 0.19 \\
\hline EG & -1.61 & 0.66 & -1.37 & 0.99 \\
\hline SG & -1.90 & 0.39 & -1.81 & 0.91 \\
\hline$P G$ & -0.91 & 0.98 & -1.50 & 0.98 \\
\hline$\Delta Y$ & $-5.82^{* * *}$ & 0.00 & $-5.89^{* * *}$ & 0.00 \\
\hline$\Delta \mathrm{OG}$ & $-4.03^{* * *}$ & 0.00 & $-4.58^{* * *}$ & 0.00 \\
\hline$\triangle \mathrm{EGL}$ & $-3.32^{* * *}$ & 0.00 & $-3.58^{* * *}$ & 0.00 \\
\hline$\Delta S G L$ & $-4.08^{* * *}$ & 0.00 & $-4.15^{* * *}$ & 0.00 \\
\hline$\triangle P G L$ & $-3.92^{* * *}$ & 0.00 & $-4.24^{* * *}$ & 0.00 \\
\hline
\end{tabular}

The critical value (CV) at \%10 is -2.21 ; CV5 is -2.33 ; CV1 is -2.55 with constant, while CV10 is -2.73 ; CV5 is -2.84 ; CV10 is -3.06 with contend and trend. ${ }^{* *}$ and ${ }^{* * *}$ indicate statistical significance at the $5 \%$ and $1 \%$ levels, respectively

Table 3 PMG estimation of ARDL $(2,1)$ for model 1

\begin{tabular}{|c|c|c|c|c|c|c|}
\hline \multicolumn{7}{|c|}{ Panel A: PMG estimation } \\
\hline Variable & \multicolumn{2}{|l|}{ Coefficient } & \multicolumn{2}{|c|}{ Std. error } & $t$ statistic & $P$ value \\
\hline \multicolumn{7}{|c|}{ Long-run results } \\
\hline OG & \multicolumn{2}{|l|}{$0.15^{* * *}$} & \multicolumn{2}{|l|}{0.006} & 24.66 & 0.00 \\
\hline \multicolumn{7}{|c|}{ Short-run results } \\
\hline ECT & \multicolumn{2}{|l|}{$-0.89^{* * *}$} & \multicolumn{2}{|l|}{0.21} & -4.23 & 0.00 \\
\hline$D(Y(-1))$ & \multicolumn{2}{|l|}{-0.06} & \multicolumn{2}{|l|}{0.09} & -0.64 & 0.52 \\
\hline $\mathrm{D}(\mathrm{OG})$ & \multicolumn{2}{|l|}{-0.07} & \multicolumn{2}{|l|}{0.33} & -0.22 & 0.83 \\
\hline \multicolumn{7}{|c|}{ Panel B: Short-run coefficients of each country } \\
\hline Variable & Bangladesh & Bhutan & & India & Nepal & Pakistan \\
\hline ECT & $\begin{array}{l}-1.28^{* * *} \\
(0.00)\end{array}$ & $\begin{array}{l}-0.57^{* * *} \\
(0.00)\end{array}$ & & $\begin{array}{l}-1.28^{* * *} \\
(0.00)\end{array}$ & $\begin{array}{l}-1.08^{* * *} \\
(0.00)\end{array}$ & $\begin{array}{l}-0.23^{* * *} \\
(0.00)\end{array}$ \\
\hline $\mathrm{D}(\mathrm{OG})$ & $\begin{array}{l}0.27^{* *} \\
(0.04)\end{array}$ & $\begin{array}{l}-1.24 \\
(0.17)\end{array}$ & & $\begin{array}{l}0.47^{* *} \\
(0.03)\end{array}$ & $\begin{array}{l}0.47^{* * *} \\
(0.00)\end{array}$ & $\begin{array}{l}-0.32^{* *} \\
(0.01)\end{array}$ \\
\hline
\end{tabular}

** and ${ }^{* * *}$ indicate statistical significance at the $5 \%$ and $1 \%$ levels, respectively. Dependent variable: Real GDP Growth ( $($ ); Independent variable: Overall Globalization Index of KOF (OG). $P$ values of the corresponding statistics in Panel B are in parentheses

The Pooled Mean Group (PMG) estimator restricts the long-run coefficients to be equal over the cross section (homogeneous) but allows for the short-run coefficients and error variances to differ across groups on the cross section (heterogeneous). A 2004 study by Liew asserts that the optimal lag should be selected based on Akaike information criterion (AIC), which is considered more suitable for sample lower than 60 cross-sectional observations (as cited in Aliyu and Ismail (2015, p. 31). Therefore, the appropriate lag orders are selected using the AIC criterion as the technique takes into account all possible lag orders on all variables and chooses the specification with the best AIC value. AIC selects ARDL $(2,1)$ for model 1 and ARDL $(1,1,1,1)$ for model 2 from a maximum 2 lag order.

Based on the PMG estimators, Panel A of Table 3 shows the results of the short-run and long-run relationship between overall globalization and economic growth, while Panel B shows the individual country-specific short-run results for model 1. According 
Table 4 PMG estimation of ARDL $(1,1,1,1)$ for model 2

\begin{tabular}{|c|c|c|c|c|c|c|}
\hline \multicolumn{7}{|c|}{ Panel A: PMG estimation } \\
\hline Variable & \multicolumn{2}{|l|}{ Coefficient } & \multicolumn{2}{|l|}{ Std. error } & \multirow[t]{2}{*}{$t$ statistic } & \multirow[t]{2}{*}{$P$ value } \\
\hline \multicolumn{5}{|c|}{ Long-run results } & & \\
\hline EG & $0.15^{* * *}$ & & 0.04 & & 3.62 & 0.00 \\
\hline SG & -0.03 & & 0.05 & & -0.58 & 0.56 \\
\hline$P G$ & $0.03^{* * *}$ & & 0.01 & & 2.93 & 0.00 \\
\hline \multicolumn{7}{|c|}{ Short-run results } \\
\hline ECT & $-0.86^{* * *}$ & & 0.14 & & -6.09 & 0.00 \\
\hline $\mathrm{D}(\mathrm{EG})$ & -0.19 & & 0.19 & & -1.06 & 0.29 \\
\hline $\mathrm{D}(\mathrm{SG})$ & 0.12 & & 0.12 & & 1.01 & 0.31 \\
\hline $\mathrm{D}(\mathrm{PG})$ & -0.01 & & 0.09 & & -0.07 & 0.95 \\
\hline \multicolumn{7}{|c|}{ Panel B: Short-run coefficients of each country } \\
\hline Variable & Bangladesh & Bhutan & & India & Nepal & Pakistan \\
\hline ECT & $\begin{array}{l}-0.87^{* * *} \\
(0.00)\end{array}$ & $\begin{array}{l}-0.78^{* * *} \\
(0.00)\end{array}$ & & $\begin{array}{l}-1.12^{* * *} \\
(0.00)\end{array}$ & $\begin{array}{l}-1.15^{* * *} \\
(0.00)\end{array}$ & $\begin{array}{l}-0.37^{* * *} \\
(0.00)\end{array}$ \\
\hline $\mathrm{D}(\mathrm{EG})$ & $\begin{array}{l}-0.07 \\
(0.76)\end{array}$ & $\begin{array}{l}-0.92^{* *} \\
(0.01)\end{array}$ & & $\begin{array}{l}-0.09 \\
(0.40)\end{array}$ & $\begin{array}{l}0.14 \\
(0.26)\end{array}$ & $\begin{array}{l}-0.03 \\
(0.48)\end{array}$ \\
\hline $\mathrm{D}(\mathrm{SG})$ & $\begin{array}{l}0.41 \\
(0.49)\end{array}$ & $\begin{array}{l}-0.16 \\
(0.89)\end{array}$ & & $\begin{array}{l}0.26^{* *} \\
(0.02)\end{array}$ & $\begin{array}{l}0.24^{* *} \\
(0.03)\end{array}$ & $\begin{array}{l}-0.16^{* *} \\
(0.02)\end{array}$ \\
\hline$D(P G)$ & $\begin{array}{l}-0.03 \\
(0.31)\end{array}$ & $\begin{array}{l}-0.26^{*} \\
(0.08)\end{array}$ & & $\begin{array}{l}0.24^{* * *} \\
(0.00)\end{array}$ & $\begin{array}{l}0.15^{* * *} \\
(0.00)\end{array}$ & $\begin{array}{l}-0.13^{* * *} \\
(0.00)\end{array}$ \\
\hline
\end{tabular}

* **, and ${ }^{* * *}$ indicate statistical significance at the $10 \%, 5 \%$, and $1 \%$ levels, respectively. Dependent variable: Real GDP Growth ( $Y$; Independent variable: $E G$ Economic Globalization Index, SG Social Globalization Index, and $P G$ Political Globalization Index of KOF. $P$ values of the corresponding statistics in Panel B are in parentheses

to the PMG estimators in Table 3, the coefficient of OG is statistically significant at the $1 \%$ significance level, and the effect is positive. The result implies that when overall globalization index of the South Asian countries increases by 1\%, the economic growth increases about $0.15 \%$. In addition, the speed of adjustment parameter $(-0.89)$ is negative and significant, which implies that $89 \%$ of the last year's disequilibrium is corrected this year. These findings show the existence of the long-run relationship between overall globalization and real GDP growth in South Asian countries; however, short-run coefficients of this model are statistically insignificant even at the $10 \%$ significance level. The individual country-wise error correction terms are statistically significant and negative at the \%1 significance level for all countries (Panel B). The error correction terms of Bangladesh, India, and Nepal are found quite high indicating that the speed of reaching equilibrium is very high in the long-run. Looking at the individual country regressions, we find that the overall globalization significantly influences economic growth in all sample countries except Bhutan.

Panel A of Table 4 shows the results of the short-run and long-run relationship between economic growth and three dimensions of globalization for the South Asian countries for model 2. Results reveal that a positive and highly significant long-run cointegration relationship exists between economic growth and economic globalization. Political globalization also accelerates economic growth in the long-run as the coefficient is significant at the $1 \%$ level; however, social globalization does not have any significant impact on economic growth in South Asian countries. The negative and highly significant error 
correction term also gives evidence of the long-run relationship between globalization (economic and political) and real GDP growth in South Asian countries. Turning to short-run coefficients of Panel A, the results of PMG estimation are very different compared to the long-run coefficients. All the short-run coefficients of this model are statistically insignificant even at the $10 \%$ significance level; however, only social globalization has a short-run positive impact on economic growth in South Asian countries.

Country-specific short-run coefficients in Panel B of Table 4 show that all the error correction terms are significant and negative at the $1 \%$ significance level. Focusing on the individual country regressions, we find that the social and political globalization significantly prompts economic growth in India and Nepal in the short-run, while they have a negative impact on Pakistan economy. Moreover, the economic and political globalization significantly decelerate economic growth in Bhutan, while they also have a negative but insignificant impact on Bangladesh economy in the short-run.

\section{Conclusion}

This study investigates the impact of KOF overall globalization index on economic growth of five South Asian countries, such as Bangladesh, Bhutan, India, Nepal, and Pakistan over the period from 1971 to 2014 employing cross-sectional dependence test, CADF unit root test (Pesaran 2007), and PMG panel cointegration analysis (Pesaran et al. 1999). Results of the cross-sectional dependence test show the evidence of cross-sectional dependency on all variables. The CIPS statistic of CADF unit root test results reveal that the individual series are either $\mathrm{I}(0)$ or $\mathrm{I}(1)$ and most importantly, none of the variables are integrated of order two. The PMG estimations of model 1 (economic growth is the dependent variable and overall globalization index is independent variable) show that a long-run relationship exists between overall globalization and real GDP growth in South Asian countries. When economic growth is considered as dependent on economic globalization index, social globalization index, and political globalization index, results of PMG test reveal that economic and political globalization accelerate economic growth in the long-run, while social globalization does not have any significant impact in South Asian countries. The result implies that when overall globalization and economic globalization of the South Asian countries increase $1 \%$, the economic growth increases about $0.15 \%$ in the long-run. In addition, all the error correction terms of the models are found negative as expected and highly significant; however, the short-run coefficients of the variables are statistically insignificant even at the $10 \%$ significance level. Based on the individual country regressions, we notice that the overall globalization significantly influences economic growth in all sample countries except Bhutan in the short-run. Moreover, the social and political globalization significantly prompt economic growth in India and Nepal in the short-run, while they have a negative impact on Pakistan economy. Moreover, the economic and political globalization significantly decelerate economic growth in Bhutan, while they also have a negative but insignificant impact on Bangladesh economy in the short-run. This individual countrywise short-run results thus reflect individual characteristics of the country's economy, such as the elasticity of the economy and the strength of political, social, and economic institutions.

We conclude that the overall globalization, economic globalization, and political globalization accelerate economic growth in the long-run in South Asian countries. The results of this study partially support Ying et al. (2014), while entirely supporting 
Kilic (2015) as he asserts economic and political globalization are more effective in the growth process of developing countries compared to social globalization. We also find support from Maqbool-ur-Rahman (2015) who finds that overall index of globalization may affect the rate of economic growth in Bangladesh, India, and Pakistan. Therefore, authorities of South Asian countries should realize the importance of globalization as a powerful influencing force and should adopt the new circumstances of globalization quickly and try to find comprehensible policies to be connected with an evolving world.

\section{Additional file}

Additional file 1. Datasets.

Acknowledgements

Not applicable.

Authors' contributions

The author read and approved the final manuscript.

Funding

The author declares that he did not receive any sorts of fund for accomplishing this research.

Availability of data and materials

The dataset used and analyzed during the current study is submitted as an Additional file 1.

Competing interests

The author declares that he has no competing interests.

Author details

${ }^{1}$ Bangladesh Civil Service (General Education), Ministry of Education, Dhaka, Bangladesh. ${ }^{2}$ Shahid Buddhijibi Government College, Rajshahi 6203, Bangladesh.

\section{Appendix}

\section{Components of 2017 KOF Index of Globalization}

\begin{tabular}{lc}
\hline Indices and variables & Weights \\
\hline A. Economic globalization & {$[36 \%]$} \\
(i) Actual Flows & $(50 \%)$ \\
Trade (percent of GDP) & $(21 \%)$ \\
Foreign Direct Investment, stocks (percent of GDP) & $(28 \%)$ \\
Portfolio Investment (percent of GDP) & $(24 \%)$ \\
Income Payments to Foreign Nationals (percent of GDP) & $(27 \%)$ \\
(ii) Restrictions & $(50 \%)$ \\
Hidden Import Barriers & $(22 \%)$ \\
Mean Tariff Rate & $(28 \%)$ \\
Taxes on International Trade (percent of current revenue) & $(26 \%)$ \\
Capital Account Restrictions & $(24 \%)$ \\
B. Social Globalization & {$[37 \%]$} \\
(i) Data on Personal Contact & $(33 \%)$ \\
Telephone Traffic & $(25 \%)$ \\
Transfers (percent of GDP) & $(2 \%)$ \\
International Tourism & $(26 \%)$ \\
Foreign Population (percent of total population) & $(21 \%)$ \\
International letters (per capita) & $(25 \%)$ \\
(ii) Data on Information Flows & $(36 \%)$ \\
Internet Users (per 1000 people) & $(37 \%)$ \\
\hline
\end{tabular}


Indices and variables

Television (per 1000 people)

Trade in Newspapers (percent of GDP)

(iii) Data on Cultural Proximity

Number of McDonald's Restaurants (per capita)

Number of IKEA (per capita)

Trade in books (percent of GDP)

C. Political globalization

Embassies in Country

Membership in International Organizations

Participation in U.N. Security Council Missions

International Treaties

Received: 16 November 2018 Revised: 21 June 2019 Accepted: 15 July 2019

Published online: 26 July 2019

\section{References}

Akhtar S (2013) Speech under the agenda item on globalization and interdependence, United Nations, 23 October 2013, New York, USA. http://www.un.org/en/development/desa/usg/statements/asg/2013/10/report-of-the-secretarygeneral-on-globalization-and-interdependence.html

Aliyu AJ, Ismail NW (2015) Foreign direct investment and pollution haven: does energy consumption matter in African countries? Int J Econ Manag 9(1):21-39

Asian Development Bank (ADB) (2017) Booming South Asia is driving economic growth in Asia, Manila, Philippines. https ://www.adb.org/news/features/booming-south-asia-driving-economic-growth-asia

Barry H (2010) Globalization and economic growth in sub-Saharan Africa. Gettysburg Econ Rev 4:42-86. http://cupol a.gettysburg.edu/ger/vol4/iss $1 / 4$

Bhattacharya D (2004) Globalization and the state: human development and capacity building needs-a review of Asian countries experiences. Globalization and the State: challenges for economic growth and human development. Department of Economic and Social Affairs, New York

Breusch TS, Pagan AR (1980) The Lagrange Multiplier test and its application to model specification in econometrics. Rev Econ Stud 47:239-254

Dreher A (2005) Globalization and taxation in the OECD: evidence from a new indicator of integration. Public Fin Manag 5(3):400-420

Dreher A (2006) Does globalization affect growth? empirical evidence from a new index globalization. Appl Econ 38(10):1091-1110

Dreher A, Gaston N, Martens P (2008) Measuring globalization-gauging its consequence. Springer, New York

Dumitrescu El, Hurlin C (2012) Testing for Granger non-causality in heterogeneous panels. Econ Model 29(4):1450-1460

Hoyos RED, Sarafidis V (2006) Testing for cross-sectional dependence in panel-data models. Stata J StataCorp LP 6(4):482-496

Kilic C (2015) Effects of globalization on economic growth: panel data analysis for developing countries. Econ Insights Trends Chall 4(127):1-11

KOF (2017) Index of globalization. http://globalization.kof.ethz.ch/

Maqbool-ur-Rahman M (2015) Impacts of globalization on economic growth-evidence from selected South Asian countries. J Manag Sci 2(1):185-204. https://doi.org/10.20547/jms.2014.1502103

Moghaddam AA, Redzuan M (2012) Globalization and economic growth: a case study in a few developing countries (1980-2010). Res World Econ 3(1):54-62. https://doi.org/10.5430/rwe.v3n1 p54

Pedroni P (1999) Critical values for cointegration tests in heterogeneous panels with multiple regressors. Oxford Bull Econ Stat 61(S1):653-670

Pedroni P (2001) Purchasing power parity tests in cointegrated panel. Rev Econ Stat 83(4):727-731

Pedroni P (2004) Panel cointegration: asymptotic and finite sample properties of pooled time series tests with an application to the PPP hypothesis. Econometric Theory 20(3):597-625

Pesaran MH (2004) General diagnostic tests for cross section dependence in panels. In: CESifo working papers, no. 1233

Pesaran MH (2006) Estimation and inference in large heterogeneous panels with multifactor error structure. Econometrica 74:967-1012

Pesaran MH (2007) A simple panel unit root test in the presence of cross section dependence. J Appl Econ 22(2):265-312. https://doi.org/10.1002/jae.951

Pesaran MH, Shin Y, Smith RP (1999) Pooled mean group estimation of dynamic heterogeneous panels. J Am Stat Assoc 94(446):621-634

Pesaran MH, Ullah A, Yamagata T (2008) A bias-adjusted LM test of error cross section independence. Econ J 11:105-127

Polasek W, Sellner R (2011) Does globalization affect regional growth? evidence for NUTS-2 regions in EU-27. Economics series 266, Institute for Advanced Studies, Vienna 
Ren CC, Karim ZA, Zaidi MAS (2012) Institutions and foreign direct investment (FDI) in MENA countries: a panel ARDL study. Proceedings of the Seventh Malaysian National Economic Conference PERKEM VII, pp 1349-1355. http:// www.ukm.my/fep/perkem/contents/perkem2012-2-10.html

Rothenberg LE (2003) Globalization 101 the three tensions of globalization. The American Forum of Global Education, New York

Shariff NS, Hamzah NA (2015) A robust panel unit root test in the presence of cross sectional dependence. J Mod Appl Stat Methods 14(2):159-171. https://doi.org/10.22237/jmasm/1446351180

United Nation Development Programs (UNDP) (1999) Globalization and development. Twenty-ninth sessions, Brazil United Nations (2004) Report on the follow-up to the Worlds Summit for Social Development (WSSD): State and globalization, and the challenges for human development. Globalization and the State challenges for economic growth and human development, New York, pp 225-258

World Bank (2017a) World development indicators data. https://data.worldbank.org/data-catalog/world-developmen t-indicators

World Bank (2017b) South Asia economic focus, Spring 2017. Globalization backlash, Washington DC. https://openk nowledge.worldbank.org/handle/10986/26373

Ying Y, Chang K, Lee C (2014) The impact of globalization on economic growth. Roman J Econ Forecasting XVI I(2):25-34

\section{Publisher's Note}

Springer Nature remains neutral with regard to jurisdictional claims in published maps and institutional affiliations.

\section{Submit your manuscript to a SpringerOpen ${ }^{\circ}$ journal and benefit from:}

- Convenient online submission

- Rigorous peer review

- Open access: articles freely available online

- High visibility within the field

- Retaining the copyright to your article

Submit your next manuscript at $\gg$ springeropen.com 